\title{
Az infografika mint az információközvetítés speciális formája *
}

\author{
Baratiné Sipos Lilla Kinga
}

\begin{abstract}
"Minden új ötlet csupán egy vagy több korábbi ötletből
\end{abstract} származó keverék vagy remix."

(Austin Kleon)

A mottóul választott idézet [1], amely őszinte átfogalmazása az ősi "Nincs új a Nap alatt” közmondásunknak, tökéletesen illik a tárgyalandó témára, az infografikákra. Az ember veleszületett sajátossága a vizualitás, a látás útján gyüjtött tapasztalatok maradandó rögzítése, és ebből fakadóan a vizuális önkifejezés "kényszere". A cikk központi tárgya az infografika, mint a minket körülvevő világ egyik szembetünő, divatos, emellett, mondhatjuk, izgalmas jelensége, amely mindig újnak hat, mégis kultúránk kezdetétöl velünk él.

Mivel mindig is az információ, illetve annak több szempontú feldolgozása, kezelése volt a könyvtárak ténykedésének legföbb tárgya, ezért az összes olyan jelenséggel szóba kell állniuk, ami bármely szempontból forradalminak tekinthető és a fejlődést szolgálhatja. Ezek után pedig már kézenfekvő feltenni a következö kérdéseket: Mennyire vehetik hasznát az infografikának maguk a könyvtárak? Milyen célok érdekében alkalmazhatják sokoldalú tevékenységük során?

Tárgyszavak: alkalmazott grafika, vizuális dokumentum, vizuális kommunikáció, megjelenítés, könyvtár, kulturális szolgáltatás

\section{Amivel leggyakrabban találkozunk}

Ha első lépésként - mélyebb „búvárkodás” nélkül - a Google segítségével legkönnyebben elérhető információkat átfutjuk, látható, hogy az infografika a 2010-es évek közepétől egyre szélesebb körben van jelen a hazai könyvtárak életében, elsősorban a közönségükkel való kommunikáció és a tájékoztatás szolgálatában. Leginkább az érdeklődésre számot tartó statisztikai adatok bemutatása, a szolgáltatásmarketing és az általános tájékozódás támogatása területén találkozhatunk velük a különféle elektronikus felületeken. A megjelenítés módját tekintve túlnyomólag statikus, élénk színvilágú, kie-

\footnotetext{
* A szerzőnek a 35. Országos Tudományos Diákköri Konferencia (OTDK) Pedagógiai, Pszichológiai, Andragógiai és Könyvtártudományi Szekció Könyvtártudományi Alszekciójában az ELTE BTK Könyvtár- és Információtudományi Intézetének hallgatójaként különdíjjal jutalmazott pályamunkája alapján készült. Témavezető: Fodor János
}

gészítő szöveget tartalmazó, kisebb képi egységekből építkező vizualizációk készültek és készülnek, legtöbbször ingyenesen hozzáférhető sablonok segítségével. (1. ábra) Ez utóbbi természetesen mit sem von le értékükből, ráadásul biztosítja a gyors előállítást, az idő- és költségmegtakarítást. Könynyen emészthető, rövid idő alatt feldolgozható információadagokat dolgoznak fel és állítanak elő. Az első benyomások alapján leglényegesebb üzenetük: a könyvtárak a 21. században is léteznek, otthon vannak a reális és a virtuális térben egyaránt, szolgálnak és szolgáltatnak, szükségleteket elégítenek ki - és egyáltalán, továbbra is hangsúlyos, nélkülözhetetlen szereplői a kultúrának. Ahhoz, hogy még hatékonyabb módon tudjuk kihasználni az adatvizualizáció ezen egyre populárisabb formája nyújtotta lehetőségeket, érdemes a téma bizonyos elméleti és gyakorlati aspektusait nagyító alá venni.

Baratiné Sipos, L. K. Az infografika mint az információközvetítés speciális formája, Tudományos és Műszaki Tájékoztatás, 69(2), p. 41-49, 2022. https://doi.org/10.3311/tmt.13146 


\section{Definíció}

Ez a fogalom, ahogyan olyan sok összetett jelenség definíciója, számtalan szempont szerint megközelíthető és megragadható. A témával foglalkozó szakemberek éltek is ezzel a lehetőséggel; valójában nincs két egyforma meghatározás, csupán esetenként azonos kulcsszavak. Ezeket foglalja össze az első ábra. Az univerzálisan előforduló szóösszetétel már önmagában is sokatmondó: a kommunikáció egyik speciális formáját írja körül. Kifejezi, hogy tárgyát többcélú módon kívánja ábrázolni: gyakorta elvont, szemnek láthatatlan tartalmak vizuális megjelenítéseként szolgál. Centrális eleme az informatív jellegú illusztrá- ció [2], amely egyre bővülő tárházból válogathat. Tartalmazhat írott vagy hangzó szöveget, illetve különféle analóg vagy digitális grafikai komponenseket, újabban már audioformátumokat is. Természetesen nem pusztán mellérendelő társításról van szó, az infografika jóval többet közvetít, mint egy hagyományos értelemben vett illusztráció. Az összetevők egymásra hatásának eredményeként egy új, addig soha nem látott, vagy nem "úgy" látott jelentés születik. Az elkészítés mögött húzódó szándék a másképp, esetleg hosszadalmasan kifejthető, nehezen kódolható és komplex információk gyors, egyértelmű közvetítése, különböző célkitűzések érdekében. (2. ábra)

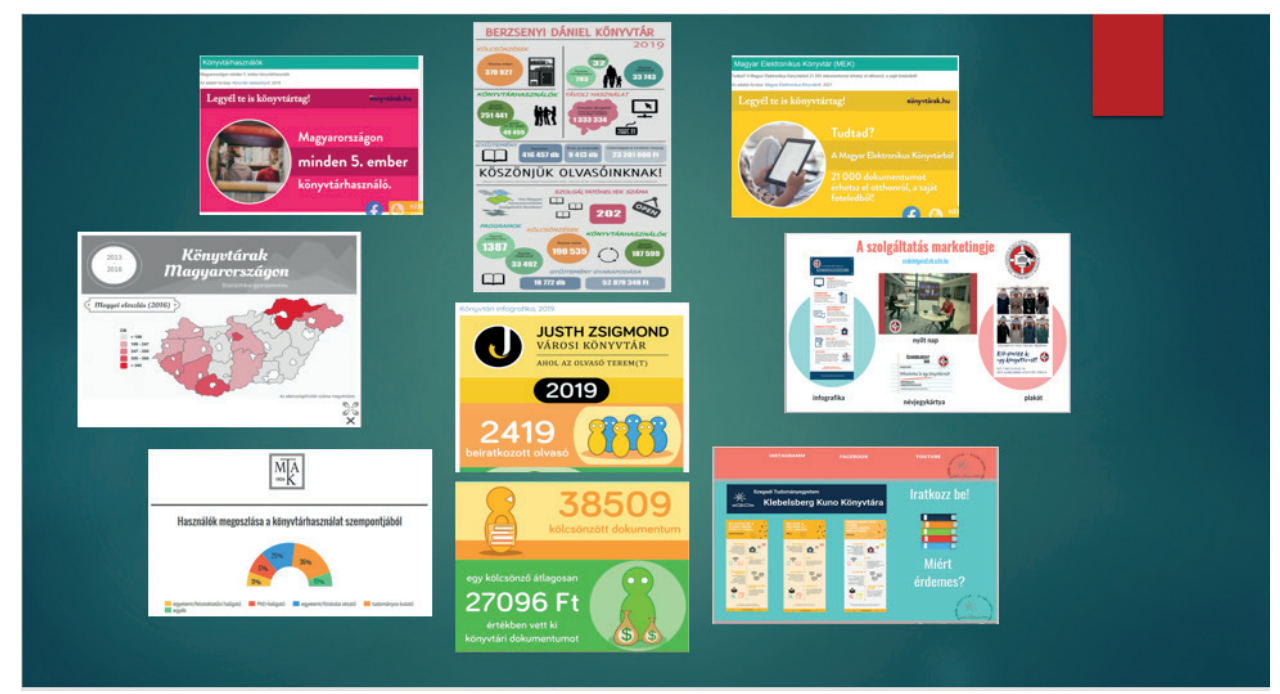

1. ábra Magyar könyvtárak infografikái

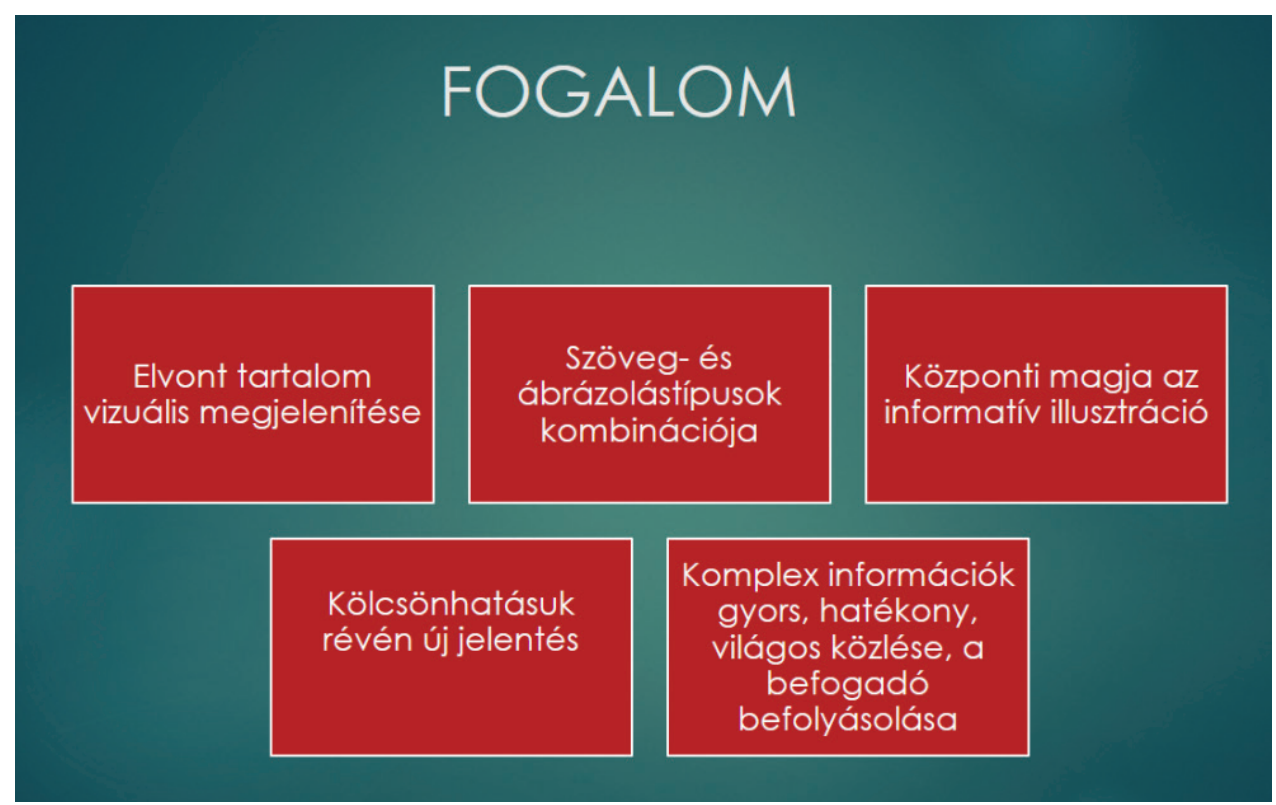

2. ábra Az infografika definíciója 


\section{Komponensek}

Az eddig elmondottak alapján kirajzolódnak a tárgyalt jelenség alapvető alkotóelemei [3], amelyek egymásra és egymásba épülve alkotnak komplex egészet. A legbelső magot azok az adatok, információk, esetleg összefüggő ismeretláncok jelentik, amelyek kifejtése, bemutatása céljából maga az infografika megszületik. Ezekre, ezekből építkezik a kommunikáció tárgyát képező, megosztandó üzenet, amely a magot alkotó adatok elemzése, a közöttük fennálló összefüggések feltárása nyomán keletkezik. E kettőt öleli fel és dolgozza át az utótagban kifejezett vizualizációs alakzat (grafika), amely az üzenet érzékekkel felfogható „testét” alkotja, éppen ezért nélkülözhetetlen. A forma, optimális esetben, egyben esztétikai élményt is nyújt, gyönyörködtető funkciót tölt be. Ez utóbbi természetesen részben a téma függvénye is, de minél „szebb” a képi megjelenítés, annál maradandóbb az emléknyom, amit az infografika maga után hagy. (3. ábra)

\section{Jellemző sajátosságok}

Az infografika felépítése során keletkező jellemzők három fő szempont köré csoportosíthatók: az informativitás, az érthetőség és a befolyásgyakorlás. (4. ábra) Az informativitás elsősorban a tartalomra utal: a közlés tárgya a feladó részéről fontosnak ítélt ismeret, üzenet, amelyet speciális, sűrített formában juttat a befogadó tudomására. Érthetőség nélkül az infografika elveszíti létjogosultságát, hiszen rezonáló befogadó híján nem képes a hatáskeltésre. Az üze-

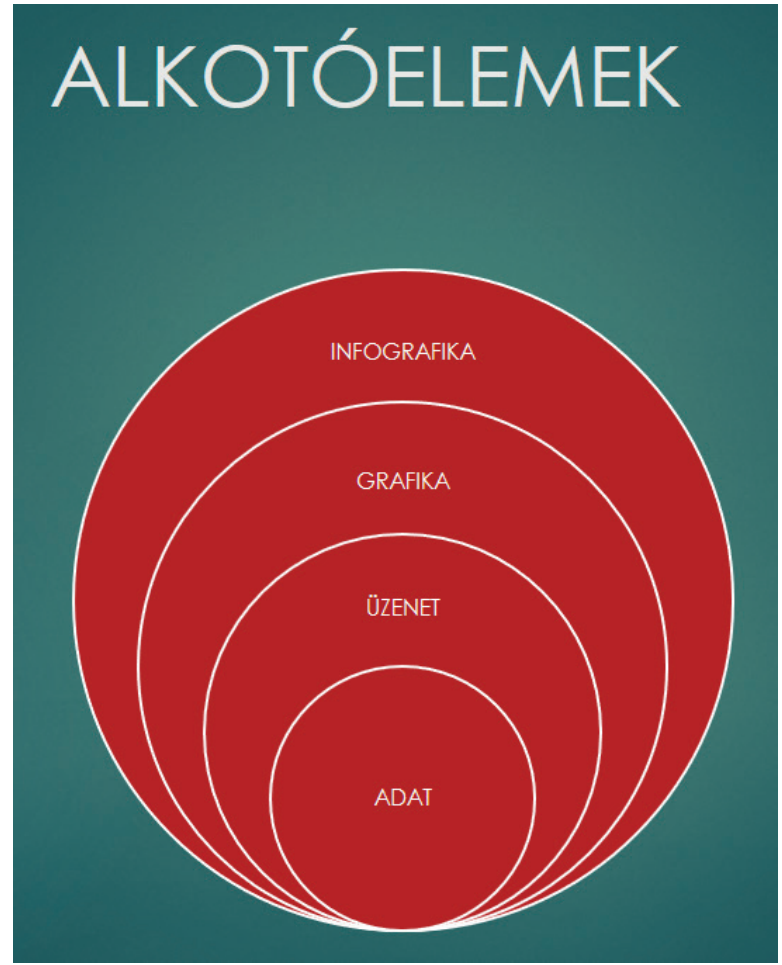

3. ábra Az infografika komponensei

net interpretációja során nem lehetnek alternatívák, azaz az infografika nem lehet többértelmű, illetve a megjelenítés formátuma figyelembe veszi az adott kulturális közeg sajátosságait, továbbá a célközönség figyelmének korlátait. A harmadik és nem nélkülözhető tulajdonsága nem titkolt célzatosságában rejlik: arra törekszik, hogy minél kizárólagosabban és tartósabban megragadja a néző figyelmét, s ezáltal egy bizonyos, kívánt irányban cselekvésre, állás-

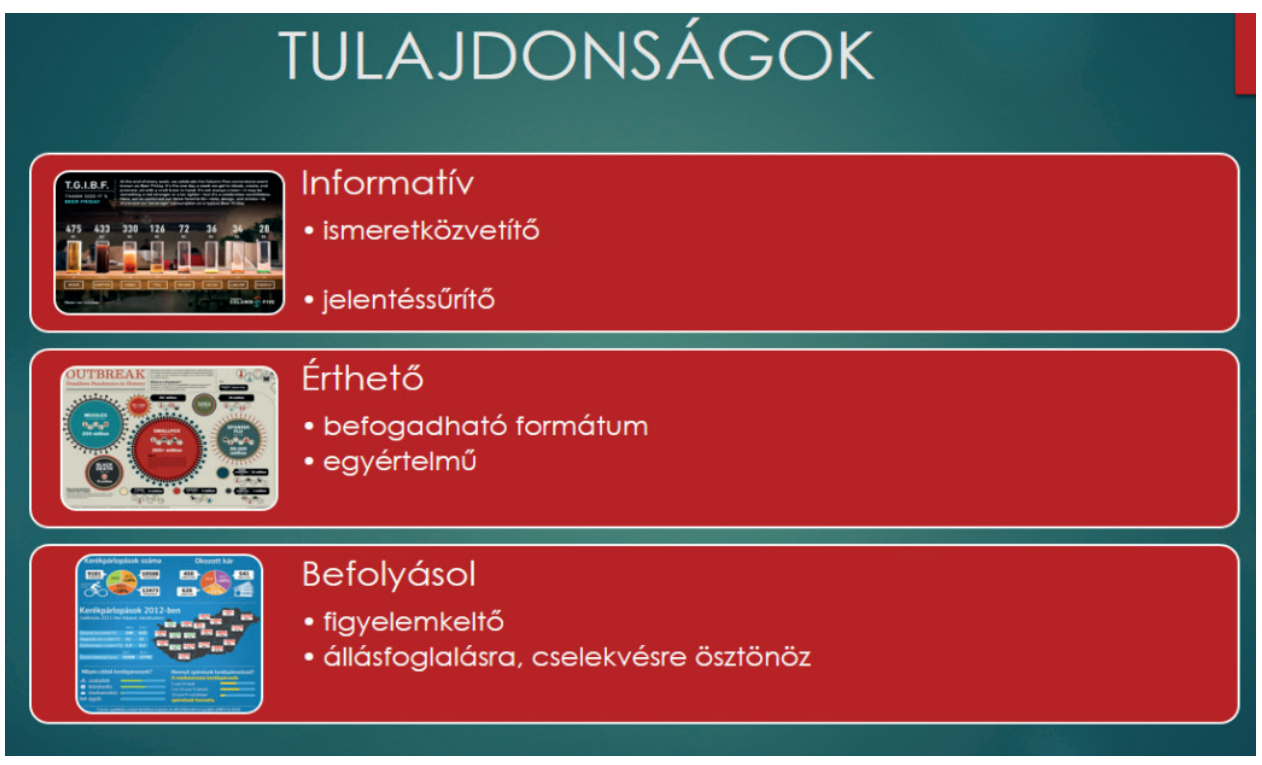

4. ábra Az infografika speciális jellemzői 
foglalásra serkentse közönségét. [4] Természetesen számtalan egyéb, járulékos karakterjegy létezik, amelyek emelik az adott infografika értékét, úgymint a megjegyezhetőség, előhívhatóság, a tájékozódástámogatás, az etikusság, megbízhatóság. [5]

\section{A siker feltételei}

Az infografika készítése komoly, összetett feladat, amely jól prosperáló szakmává-iparággá nőtte ki magát az elmúlt évtizedekben. Ahhoz, hogy a produktum a kívánt hatást elérhesse, egyáltalán kitűnjön a tömegből, számtalan feltételnek kell megfelelnie. Ahogyan a fogalommeghatározás esetében tapasztalható volt, itt is igaz, hogy ahány megközelítés, annyiféle elvárás fogalmazódik meg a végtermékkel kapcsolatosan. Ezen belül van azonban egy közös szabálykészlet, amely kiindulópontként szolgálhat az elkészítés során. (5. ábra)

Az üzenet hatékony és lehető legpontosabb vizuális megformálása során soha nem szabad szem elől veszíteni a tényt, hogy a megjelenítendő tartalom a lényeg, amellyel szemben alapelvárás a hitelesség, visszakereshetőség és ellenőrizhetőség. Utóbbiak hiányában joggal kérdőjelezhető meg az infografika létrehozójának legjobb szándéka is.

A tartalmat jelentő adatgyüjteményt egységes szerkezetbe, szisztematikus rendszerbe foglalva kell "tálalni" a többszintű megjelenítés érdekében. Kínáljon lehetőséget a befogadónak, hogy akár mikro-, akár makroszintról indulva, a legkisebb erőbevetéssel tanulmányozhassa az elétárt tartalmat. Ez azonban csupán akkor valósulhat meg, ha a feladó világosan meghatározott céljai érdekében született, legyen az például folyamatábrázolás, összefüggések feltárása, marketing stb. Mindannak, amit az infografika

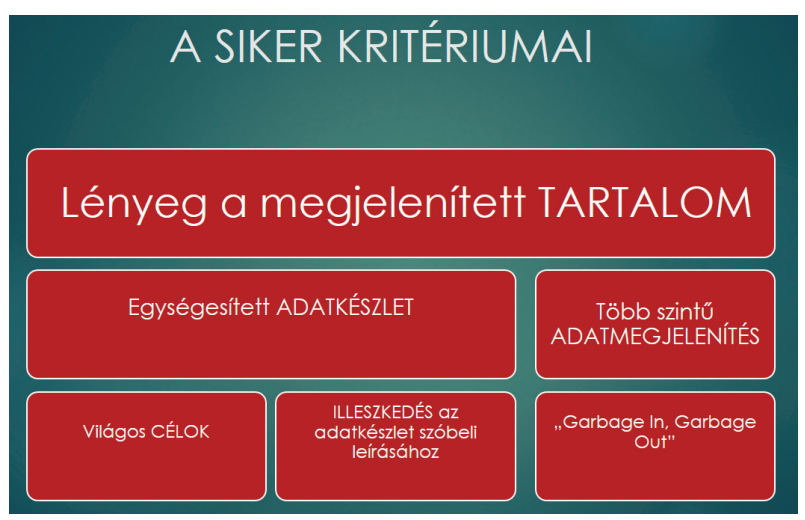

5. ábra A sikeresség feltételei láttat, teljes összhangban kell lennie a mögöttes, esetleg láthatatlan adatkészlet szóbeli leírásával. [6] Magától értetődő kritérium az egészséges minimalizmusra törekvés, legalábbis ami a közvetített tartalmat és a megjelenítés formáját illeti. $A$ végleges figyelemvesztést kockáztatja, aki túllép bizonyos méreteket, ezért mindenképpen indokolt a "kevesebb több" elvének érvényesítése. A vizualizáció során a tipológia, a színek, a grafikai elemek kiválasztása és összekapcsolása során a harmóniára és áttekinthetőségre törekvés mellett az esztétikai szempontokat is célszerű figyelembe venni. [7] Az alapkövetelmények közé sorolható, hogy érdeklődésre számot tartó, valamilyen szempontsor alapján jelentős információkat közvetítsen a lehető legkisebb térfoglalással, a legrövidebb időtartam alatt. $\mathrm{Az}$ érdektelen témaválasztás egyértelműen minden infografika halála. Ugyanakkor mindenképpen a sikert szolgálja, ha a kölcsönös kommunikáció eszközeként szolgálhat a feladó és a befogadó között. [8] Végül meg kell említeni a kiválóság talán legfontosabb fokmérójét, amely ugyan nem minden esetben elengedhetetlen, mégis emeli a termék értékét: ez pedig az addig láthatatlan információ megláttatása, esetlegesen új, korábban fel nem tárt összefüggések, következtetések stb. vizualizációja. [9]

\section{Az infografika típusai}

Az eddig tárgyalt altémákhoz képest az infografikák tipológiája [10] mutatja a legnagyobb "széttartást"; aligha lehet egységes rendszer keretei közé szorítani a sokféle csoportosítási módozatot. Egy-egy szakíró esetében is jellemző, hogy többféle szempont szerint többféle típustant állít fel. Ezen túlmenően maguk az infografikák is csak nagyon ritka esetben sorolhatók egyetlen kategóriába. További problémát vet fel, hogy az egyes vizualizációtípusok elnevezései gyakran nem egyértelműek, illetve átfedéseket tartalmaznak, vagy éppen a magyar nyelvű megfelelőjük sugallhat kétértelműséget.

Alapvetően négyféle szempont alapján állíthatunk fel kategóriákat: a tartalom, vagyis a tematika; a megjelenítés módszere; a felhasználási terület; illetve a célközönség alapján. Természetesen leggyakrabban ezek - esetenként többszörös - kombinációja valósul meg. A tartalmat illetően elkülönülhet az egyes tudományágak szerint, vagy éppen a megjelenített információk közötti viszonyrendszer 
alapján: ok-okozat, előzmény-következmény, kronologikus rend, ellentétek, analógiák stb. A megjelenítés alapvetően kétféle lehet: analóg, tehát hagyományosan papíralapú, illetve digitális. Az utóbbi csoport folyamatos fejlődésben van, a statikus, állóképszerü infografikáktól rohamtempóban jutott el a világ a dinamikus, ma már gyakran interaktív, azaz a befogadót is bevonó ábrázolásokig, illetve az audiovizuális, multinarratív feldolgozások köréig. (6. ábra) A felhasználási területek, illetve a célközönség szempontjaira a későbbiekben térünk ki.

\section{Az infografika alkalmazásának céljai}

Az infografika kommunikációba történő beiktatása alapvetően három, szervesen egymásra épülő cél kielégítését szolgálhatja: közlés, elemzés, befolyásolás. (7. ábra) A közlés lefedi az adatokra épülő információk továbbadását, bemutatását, újszerü, egyedi módon történő prezentálását. Az elemzés a legkülönfélébb viszonyrendszerek feltárását célozza: az összevetés eredményeként analógiák és kontrasztok, ok-okozati összefüggések, előzmény-következmény szintű kapcsolatok, mintázatok, törvényszerúségek hangsúlyozására kerülhet sor. A harmadik szint a befolyásgyakorlás, amely lehet politikai, üzleti, társadalmi célzatú egyaránt. [11] Fontos szempont, hogy az egyszerüsítés, mint cél csak korlátozott formában értendő; ellenkező esetben torz, sekélyes, információhiányos vizualizációk születnek. [12] Amennyiben etikai szempontokat is figyelembe veszünk, fel sem merülhet a befogadók szándékolt félrevezetése, fals üzenetek által indukált döntésekre való késztetése.

\section{Az infografika-készítés legfontosabb lépcsői}

A How to make? kérdésre adott válaszokat [13] legegyértelmúbben három fázisra lehet elkülöníteni. E nagy szakaszok szorosan egymásra épülnek, és külön-külön is sok apró lépésből tevődnek össze: igénymegfogalmazás, kivitelezés, hatásfelmérés. (8. ábra) Ezeken belül az egyes tennivalók sorrendje adott esetben felcserélhető, kombinálható, akár ismételhető. Igénymegfogalmazás alatt azt értjük, hogy pontosan kijelöljük a készítendő termék tárgykörét, felmérjük az időkorlátokat, meghatározzuk azt az összefüggéshálót, amelyben az infografika elhelyezendő. Csak akkor léphetünk tovább, ha hajszálpontosan tudjuk, mit akarunk közvetíteni, tárgyunkat milyen információkészlet alapján formáljuk meg, milyen célközönség számára, és mi lesz ezek alapján maga az üzenet. Talán a következő, a kivitelezési fázis a legidőigényesebb, különösen akkor, ha valaki először fog bele egy infografika elkészítésébe. llyen esetben mindig érdemes először alaposan tájékozódni a jelenlegi

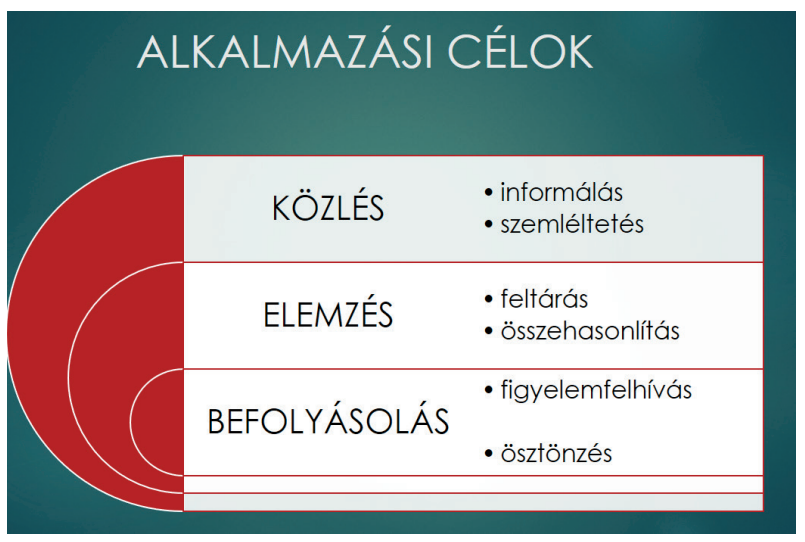

7. ábra Az infografika alkalmazási célkitűzései

\begin{tabular}{|c|c|c|c|c|}
\hline & 1. & 2. & 3. & 4. \\
\hline TÍPUSOK & $\begin{array}{l}\text { média } \\
\text { vállalkozás } \\
\text { reklám } \\
\text { nyilvánosság } \\
\text { oktatás } \\
\text { akadálymentes }\end{array}$ & $\begin{array}{l}\text { nyomtatott } \\
\text { digitális } \\
\text { statikus } \\
\text { story telling } \\
\text { dinamikus } \\
\text { interaktív } \\
\text { fullpage } \\
\text { 3D-s }\end{array}$ & $\begin{array}{l}\text { tudományos } \\
\text { ismeretterjesztő }\end{array}$ & $\begin{array}{l}\text { adatvizualizálás } \\
\text { folyamatábra } \\
\text { térkép } \\
\text { plakát, összetett } \\
\text { digitális } \\
\text { 2D } \\
\text { 3D } \\
\text { interaktív } \\
\text { animált } \\
\text { multinarratív }\end{array}$ \\
\hline SZEMPONT & FELHASZNÁLÁSI TERÜLET & $\begin{array}{c}\text { ADATMEGJELENÍTÉSI } \\
\text { MÓDSZER }\end{array}$ & CÉLKÖZÖNSÉG & $\begin{array}{c}\text { ADATMEGJELENÍTÉSI } \\
\text { MÓDSZER }\end{array}$ \\
\hline FORRÁS & \multicolumn{2}{|c|}{ HEBER, Raimar } & \multicolumn{2}{|c|}{ TUDOMÁNYKOMMUNIKÁCIÓ } \\
\hline
\end{tabular}

6. ábra Néhány típuscsoport az infografikákon belül 


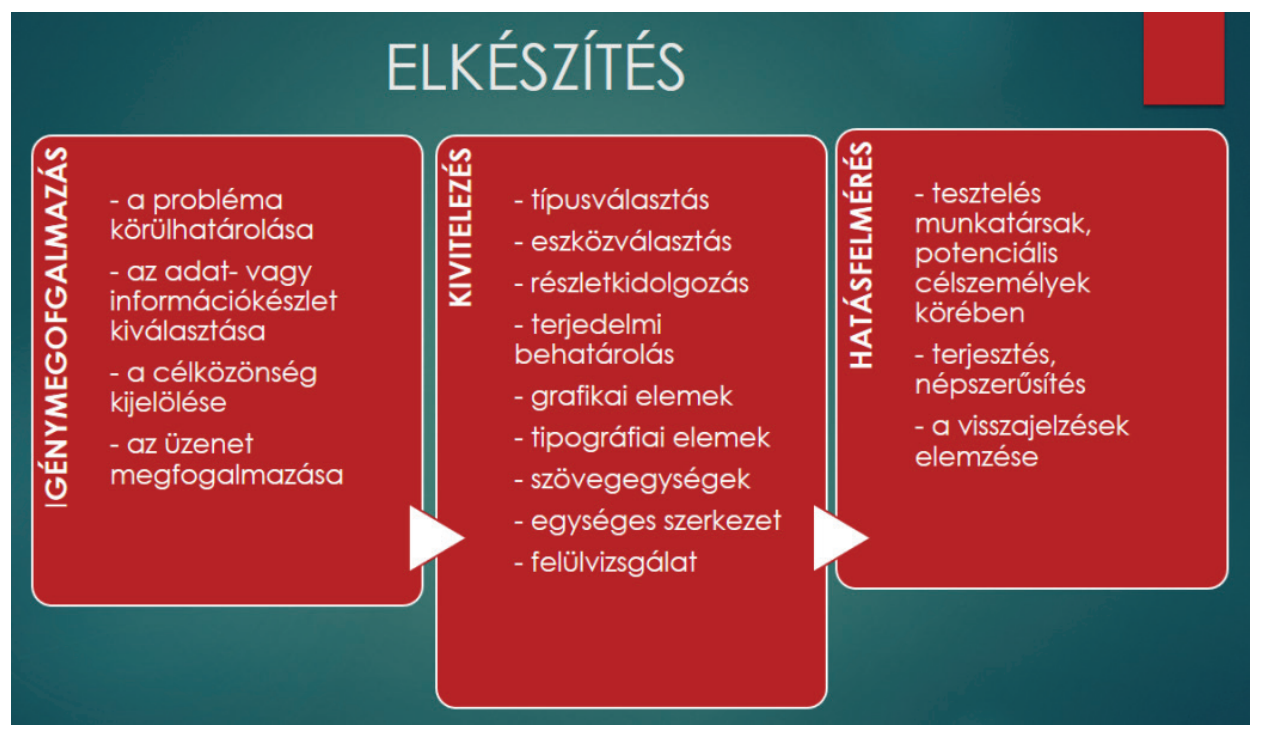

8. ábra Az infografika-készítés lépcsői

kínálati palettán: számtalan weboldal nyújt kiindulási pontot, jó példákat, ötleteket, amelyek a színvonalas formába öntést támogatják. Ilyenek többek között az Easy.ly, a Pinterest stb. De nemcsak a külalak, hanem a beltartalom esetében is léteznek források, ahol ingyenesen megbízható adatkészletekhez juthatunk (pl. https://www.columnfivemedia.com/100-best-free-data-sources-infographic). Ezután két fontos döntést kell meghozni: a korábban körülhatárolt infografikai típusok közül kiválasztjuk a téma, mondanivaló szempontjából legmegfelelőbbet, majd ennek függvényében a kivitelezés eszközét is. Lehet vektorgrafikus és kiadványszerkesztő szoftver (Adobe Illustrator, InDesign, InkScape stb.) vagy online használható megoldás (Pictochart, Canva). Az utóbbiak esetében egyre több az ún. "freemium" szolgáltatás: egy bizonyos színvonal- és igényszint esetén ingyenes sablonok közül választhat a felhasználó, illetve vannak fizetős szolgáltatások. Az eszközrendszer segítségével válik lehetségessé a részletek kidolgozása, amely magában foglalja a terjedelmi keretek behatárolását, a grafikai és tipográfiai jellemzők, a színvilág, a szöveg-kép-arányok kialakítását, egységes szerkezetbe foglalását. A kivitelezési szakasz utolsó lépése a szisztematikus felülvizsgálat. Végül a harmadik, ugyancsak lényeges fázis a hatáskövetés, szintúgy több lépcsőben. Az esetleges rejtett hibák hárítása érdekében érdemes először a munkatársak, illetve a potenciális célszemélyek körében előzetes bemutatót tartani. Ezt követi az "éles bevetés", a terjesztés, népszerűsítés, vagyis a cél- közönségnek történő eljuttatás. A fejlesztés, a siker érdekében fontos a visszajelzések kiértékelése is, ha lehetséges és szükséges, akár egy felülvizsgálatot követő javítás is.

\section{A könyvtári szféra és az infografikák}

Vannak olyan területek, mint például a média, a marketing, az egészségügy, bizonyos tudományágak, az oktatás stb., melyek előszeretettel alkalmaznak infografikákat céljaik elérése, népszerüsítése érdekében. Felmerül a kérdés, mi a helyzet a könyvtári szférával ebben a vonatkozásban. [14] A korábban elmondottak alapján megállapítható, hogy fontos érintkezési pontok mutatkoznak a két információközvetítő terület között: a végtermék mindenképpen adatbányászat és adatelemzés eredménye; fő törekvés a megbízható és hiteles információk érthető és megbízható módon történő közvetítése. (9. ábra)

Maguk a könyvtárak, mint társadalmi szükségleteket betöltő intézmények információcentrumokként funkcionálnak, amelyek exponenciálisan növekvő adatkészletekkel rendelkeznek. Tevékenységpalettájuk meglehetősen összetett, ezért az információ vizualizációja több területen is hatékony megoldást jelenthet. Emellett tudomásul kell venni, hogy a felhasználók körében a digitális bennszülöttek aránya folyamatosan nő a digitális bevándorlókkal szemben. Éppen ezért, a kapcsolatfenntartás és igénykielégítés terén is szükségszerű a folyamatos lépéstartás a legújabb módszerek és technikák alkalmazásával. 
A megcélozható befogadók köre értelemszerűen a könyvtárak legtágabb értelemben vett ügyfelei közül, kapcsolati hálójának "elemei" köréből kerül ki: a fenntartásért felelős intézmények, az olvasóifelhasználói réteg, amely számbelileg a legnagyobb csoportot alkotja, illetve magának a szakmának a képviselői. Mindegyik esetében számolhatunk a valós és a potenciális érintettekkel. (10. ábra) $\mathrm{Az}$ infografikaként megfogalmazható könyvtári üzeneteket legkönnyebben tematika alapján csoportosíthatjuk, nem technikai szempontból és nem fontossági sorrendben. A fenntartó felé elsősorban a rendszeres tájékoztatás, az érdekképviselet, a problémafeltárás, az anyagi vagy egyéb jellegú támogatás fokozásának indoklása terén lehetséges

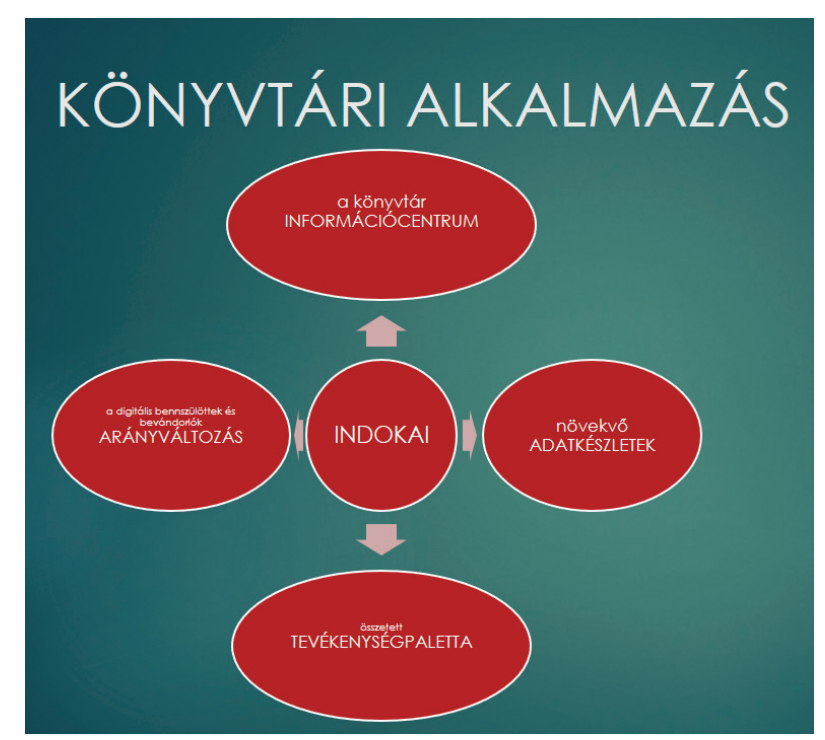

9. ábra Mi teheti indokolttá a könyvtári használatot?

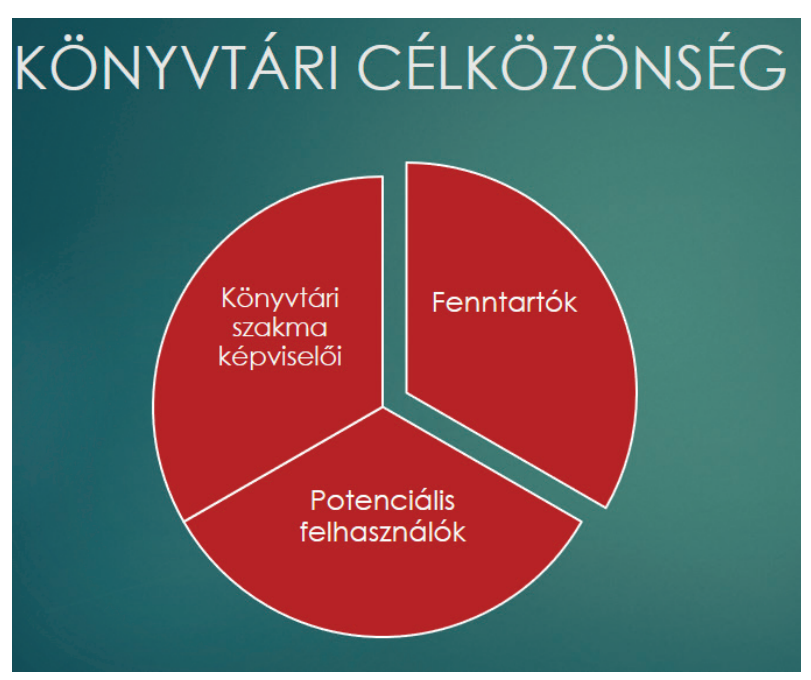

10. ábra A célközönség szegmensei a vizualizáció alkalmazása. A felhasználói kör esetén a legszélesebb a paletta: beletartozik az olvasótoborzás, az intézménybemutatás, az egyes szolgáltatások marketingje, a felhasználói kör oktatása, nevelése, az oktatás- és tanulástámogatás, szabályzatismertetések, az állomány és az egyes gyújtemények, részlegek, különlegességek prezentálása, népszerúsítése, a könyvtár speciális adatkészleteinek feltárása, adatállományainak prezentálása, de az épület(ek)en belüli tájékozódás, a megközelíthetőség bemutatása, sőt, a rendezvénypromóció is. A könyvtáron belüli kommunikáció során is hatékony eszköz lehet, többek között a használati szokások, statisztikák elemzésére, bemutatására, a stratégiaalkotás elemeként alkalmazva. A harmadik közönségcsoport irányában elsősorban talán a kooperáció lehetőségeinek, illetve elért eredményeinek prezentációja történhet infografika segítségével, legyen az lokális, regionális vagy éppen globális szintű kapcsolódási forma. (11. ábra)

\section{Jövökép}

Vannak bizonyos trendek, amelyek egymással összefonódva erőteljesen befolyásolják a könyvtárak és a könyvtárosi pálya jövőjét, $s$ ezen belül az adatvizualizáció használatát is [15]. Az online térben felhalmozott, szisztematikusan összegyújtött és folyamatosan keletkező információtömeg tovább gyarapodik, és ezzel párhuzamosan a technikai háttér sem szűnik meg fejlődni. Mindez a könyvtárakra, mint információtároló, -rendszerező és -sugárzó

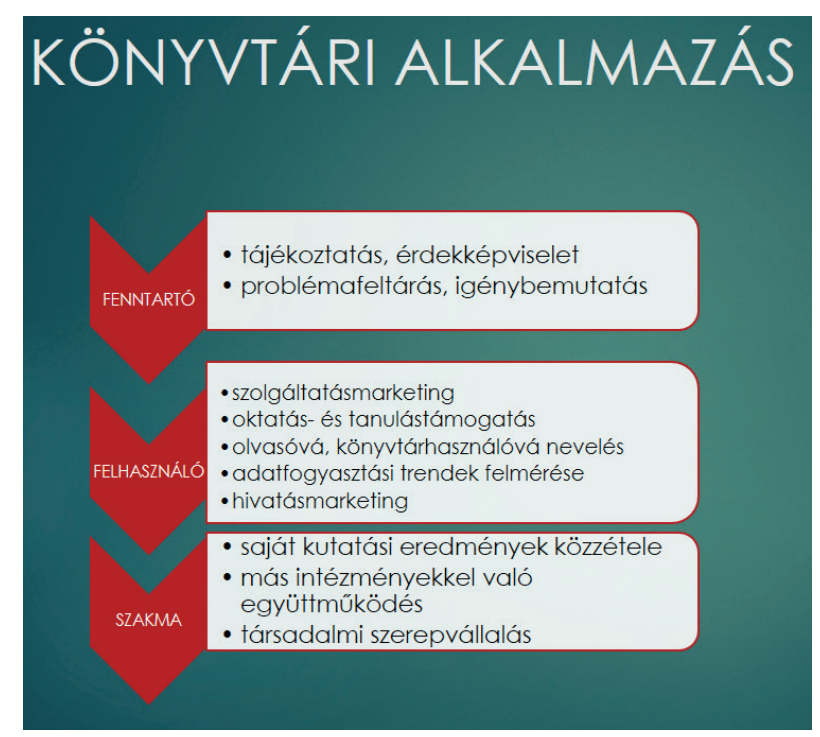

11. ábra A könyvtári alkalmazás lehetőségei 
intézményekre is óriási feladatokat ró. A lépéstartás egyenlő az e szakmára ugyancsak vonatkozó élethosszig tartó tanulásban való részvétellel, a szakma fokozatos átalakulásával. Ennek egyik lehetséges következménye lehet, hogy a könyvtárosok egy része az adatbányászat, adatelemzés, illetve az adatvizualizáció területére fog majd specializálódni, professzionális szintre emelve az infografikákban rejlő lehetőségek kiaknázását, s így ők maguk is hozzájárulnak az adattermelés végtelennek tűnő folyamához. (12. ábra)

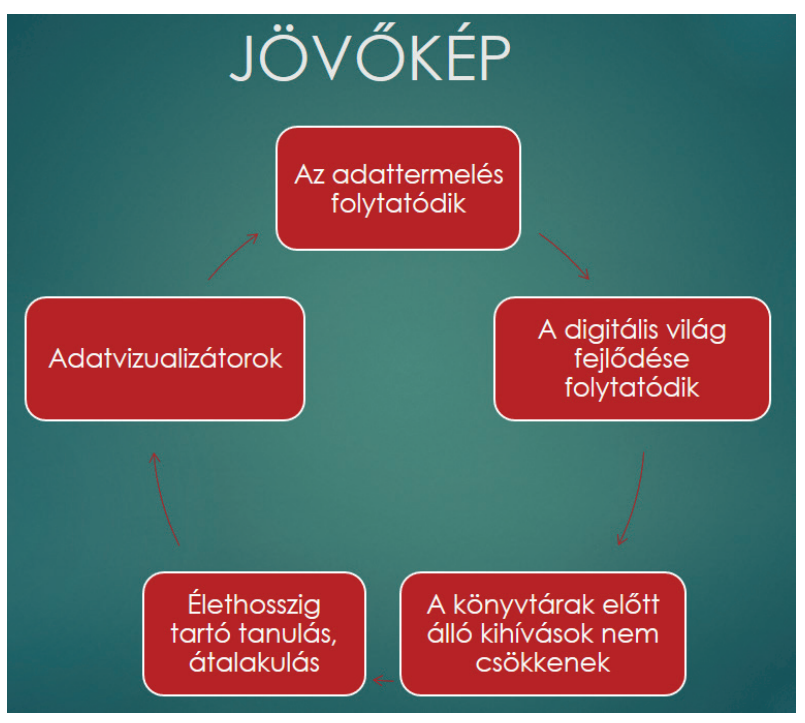

12. ábra Egy lehetséges jövőkép

\section{Irodalom}

[1] CAIRO, Alberto The Functional Art. An Introduction to Information Graphics and Visualisation. Berkeley, New Riders. 2013. 30. p. ISBN 978-0-321-83473-7

[2] SMICIKLAS, Mark: The power of infographics: Using pictures to communicate and connect with your audiences. Indianapolis, Que Pub. 2012. 15. p. ISBN-13: 978-0789749499

[3] https://hu.wikipedia.org/wiki/Infografika [Utolsó elérés: 2020. március 15.]

[4] KEEM, Aden (2017): What is an infographic? The History and Evolution of Data Visualization https://www.dailyinfographic.com/ blog/what-is-an-infographic-history-and-evolution?utm_source=dlvr.it\&utm_medium=twitter [Utolsó elérés: 2020. március 15.]

[5] HEBER, Raimar: Infografik. Gute Geschichten gut erzählen mit komplexen Daten. Bonn, Rheinwerk. 2018. 2. akt., erw. Aufl. 31. p. ISBN 978-3-8362-6438-9

[6] CHIKODI (2011): How-infographics-jumped-the-shark https://venturebeat.com/2011/12/01/how-infographics-jumped-the-shark/ [Utolsó elérés: 2020. március 15.]

[7] ADAMS, Daniel: What are Infographics and Why are they Important? 2017. http://www.instantshift.com/2011/03/25/what-areinfographics-and-why-are-they-important [Utolsó elérés: 2020. március 15.]

[8] CAIRO, Alberto The Functional Art. An Introduction to Information Graphics and Visualisation. Berkeley, New Riders. 2013. 74. p. ISBN 978-0-321-83473-7

[9] CAIRO, Alberto The Functional Art. An Introduction to Information Graphics and Visualisation. Berkeley, New Riders. 2013. 110. p. ISBN 978-0-321-83473-7

[10] VIZUALIZÁCIÓ a tudománykommunikációban. Szerk. Balázs Barbara, Bubik Veronika, Hadabás Gitta et al. Budapest, Eötvös Loránd Tudományegyetem. 2013. https://www.eltereader.hu/media/2014/05/Vizualizacio_READER.pdf [Utolsó elérés: 2020. március 15.]

[11] NACACH, Jamie: Why, How and Where to Use Infographics https://www.business2community.com/infographics/ why-how-and-where-to-use-infographics-01407374\#yZwhyypMdyFzXoWi.97 [Utolsó elérés: 2020. március 15.]

[12] CAIRO, Alberto The Functional Art. An Introduction to Information Graphics and Visualisation. Berkeley, New Riders. 2013. 75-77. p. ISBN 978-0-321-83473-7

[13] YUVARAJ, Mayank (2017): Infographics: tools for designing, visualizing data and storytelling in libraries. Library HiTechNews, Vol. 34. Issue: 5., p. 6-9. https://doi.org/10.1108/LHTN-01-2017-0004 Permanent link to this document: https://doi.org/10.1108/ LHTN-01-2017-0004 [Utolsó elérés: 2020. március 15.]

[14] PUSKÁS Nikoletta: Könyvtár, információ, grafika - középpontban az olvasói igények. = TMT. 64. évf. 2017. 11. sz. p. 560-576. http://epa.oszk.hu/03000/03071/00112/pdf/EPA03071_tmt_2017_11_560-576.pdf [Utolsó elérés: 2020. március 15.]

[15] YUVARAJ, Mayank (2017): Infographics: tools for designing, visualizing data and storytelling in libraries. Library HiTechNews, Vol. 34. Issue: 5., p. 6-9.

https://doi.org/10.1108/LHTN-01-2017-0004 [Utolsó elérés: 2020. március 15.]

\section{Beérkezett: 2022. január 24.}




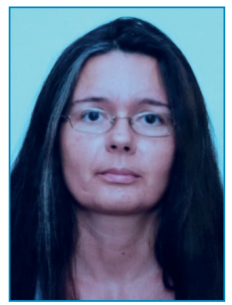

\section{Baratiné Sipos Lilla Kinga}

az ELTE BTK Könyvtár- és Információtudományi Intézet

MA hallgatója (2018-2020)

informatikus könyvtáros,

a Miskolci Egyetem Könyvtár, Levéltár, Múzeum munkatársa.

E-mail: konstans@uni-miskolc.hu 